\title{
Management of Early Blight of Potato (Solanum tuberosum L.) caused by Alternaria solani [(Ellis \& Martin) Jones \& Grout] through Fungicides and its Impact on Yield
}

\author{
R. K. Sharma ${ }^{1 *}$, J. K. Patel ${ }^{2}$, D. R. Patel ${ }^{1}$ and R. N. Patel ${ }^{2}$ \\ ${ }^{1}$ Agricultural Research Station, SDAU, Sardarkrushinagar Dantiwada Agricultural \\ University, Ladol, Mehsana, Gujarat, India - 384540 \\ ${ }^{2}$ Potato Research Station, SDAU, Deesa Agricultural Research Station \\ Sardarkrushinagar Dantiwada Agricultural University, Deesa, \\ Gujarat, India - 385535 \\ *Corresponding author
}

\begin{tabular}{l} 
K e y w o r d s \\
Potato, Early \\
Blight, Alternaria \\
solani, Fungicides, \\
Fenamidone + \\
Mancozeb, Per cent \\
Disease Intensity, \\
Efficacy and \\
management \\
Article Info \\
\hline Accepted: \\
12 February 2020 \\
Available Online: \\
10 March 2020
\end{tabular}

The efficacy of some combination fungicides like fenamidone $10 \%+$ mancozeb $50 \%$ WDG, metiram 55\% + pyraclostrobin 5\% WG and cymoxanil $8 \%+$ mancozeb $64 \% \mathrm{WP}$ along with commonly used fungicides viz., dimethomorph $50 \% \mathrm{WP}$, fosetyl $\mathrm{Al} 80 \% \mathrm{WP}$, mancozeb $75 \mathrm{WP}$, metalaxyl $8 \%+$ mancozeb 64\% WP, captan $70 \%+$ hexaconazole $\%$ WP and carbendazim 25\% + mancozeb 50\% WS were tested against early blight of potato $c v$. kufri pukhraj at Agricultural Research Station, Ladol and Potato Research Station, Deesa, S. D. Agril. University, Gujarat during 2015-16 to 2017-18. A variant with no application of fungicide was used as a control. All the treatments reduced the disease intensity significantly as compared to untreated check. The data on PDI of early blight of potato was recorded periodically at 50,60 and 70 days after sowing with consecutive three spray of fungicides at 15 days interval and was found low to moderate in range (10.07$37.98 \%$ ). The lowest per cent disease intensity (PDI) 10.07 was observed in case of fenamidone $10 \%+$ mancozeb 50\% WDG @ $0.2 \%$ treatment $(2.5 \mathrm{gm} / \mathrm{l})$ followed $\mathrm{T}_{8}$ spraying of metiram 55\% + pyraclostrobin 5\% WG @ $0.2 \%(2 \mathrm{gm} / \mathrm{l})$ and $\mathrm{T}_{2}$ spraying of cymoxanil 8\% + mancozeb 64\% WP @ 0.25\% (2.5 gm/l) with its PDI at par values. It significantly reduced the early blight as compared to control. Similarly, the highest yield of potato tubers was also recorded in $\mathrm{T}_{1}$ spraying of fenamidone $10 \%+$ mancozeb $50 \%$ WDG @ 0.2\% (2.5 gm/litre) against early blight with $51661 \mathrm{~kg} / \mathrm{ha}$ followed by metiram 55\% + pyraclostrobin 5\% WG @ 0.2\% (2.0 gm/litre) and cymoxanil 8\% + mancozeb 64\% WP @ 0.2\% (2.5 gm/litre) with its yield 49309 and $48984 \mathrm{~kg} / \mathrm{ha}$, respectively. Thus, it can be said that combination of systemic and contact fungicides effectively suppressed pre- as well as post-infection activity and inhibited sporulation and/or restricted lesion expansion of early blight pathogen. Also found increase in the yield of potato as well. 


\section{Introduction}

Potato (Solanum tuberosum L.) is one of the most important food and cash crop belonging to the family solanaceae. The major potato producing states are Uttar Pradesh, Bihar, Gujarat Karnataka, Orissa, Andhra Pradesh, Maharashtra, Madhya Pradesh, and West Bengal. In India, potato is grown in all the states producing 493 lakh tonnes from total area of 1.5 million ha (Anonymous, 2017). The crop has the potential to increase agricultural production in our region. In Gujarat, it is grown in area of 81.27 thousands ha producing 38.35 lakh tonnes which is contribute near about 8 per cent share of potato production with $30758 \mathrm{~kg} / \mathrm{ha}$ average productivity at national level (Anonymous, 2018). The major potato growing districts of Gujarat are Banaskantha, Sabarkantha, Mehsana, Patan, Gandhinagar, Surat, Valsad, Vadodara, Navasari and Dang (Anonymous. 2009). India ranked second in the potato production worldwide (Anonymous, 2017). Potato is commonly affected by numerous fungal diseases viz., Early blight [Alternaria solani (Ellis and Mart.)], Leaf blight [Alternaria alternata Fries (Keissler)], Late blight [Phytophthora infestans (Mont.) de Bary], Anthracnose [Colletotrichum phomoides (Sacc.) Chester], Fusarium wilt [Fusarium oxysporum f. sp. lycopersici (Sacc.) Snyder and Hansen], etc. Among them, early blight of potato caused by Alternaria solani is one of the common and wide spread disease.

In every year, it appears in devastating form in major potato growing areas of Gujarat. The disease mainly infects leaves and tubers. Initially the symptoms occur on the lower and older leaves in the form of small (1-2 mm) circular to oval brown spots. These lesions have the tendency to become large and angular at later stage. Mature lesions on foliage look dry and papery, and often have the concentric rings, looking like bulls eye. The symptoms on the tuber comprise of brown, circular to irregular and depressed lesions with underneath flesh turning dry, brown and corky. Lesions tend to enlarge during storage and affected tubers later become shriveled (Figure A \& B). The various factors limiting yield of potato include lack of high yielding varieties, inadequate supply of healthy seed tubers and high intensity of diseases and pests. Among the fungal diseases, early blight of potato incited by Alternaria solani [(Ellis \& Martin) Jones \& Grout] is the most destructive disease. In Gujarat, the disease occurs every year in not epidemic form but contributing to yield loss up to 30 per cent in unsprayed crop (Patel, 2007). Among the new fungicides, fenamidone $10 \%+$ mancozeb 50\% WDG and metiram $55 \%$ + pyraclostrobin $5 \% \mathrm{WG}$ have been evaluated as highly effective against $A$. solani. Both the combination of fungicides has already been used in different parts of the country for management of foliar blight of potato. However, it is quite essential to evaluate their efficacy against the disease for a particular climatic condition. Therefore, an experiment has been carried out to investigate the performance of some fungicides viz., fenamidone $10 \%$ + mancozeb 50\% WDG, cymoxanil $8 \%+$ mancozed $64 \% \mathrm{WP}$, dimethomorph 50\% WP, fosetyl Al 80\% WP, mancozeb $75 \mathrm{WP}$, metalaxyl $8 \%+$ mancozeb $64 \% \mathrm{WP}$, captan $70 \%$ + hexaconazole 5\% $\mathrm{WP}$, metiram $55 \%$ + pyraclostrobin $5 \% \mathrm{WG}$ and carbendazim 25\% + mancozeb 50\% WS under North Gujarat agro climatic conditions.

\section{Materials and Methods}

The experiment was conducted at two locations namely, Agricultural Research Station, S. D. Agricultural University, Ladol and Potato Research Station, SDAU, Deesa Gujarat during the year 2015-16 to 2017-18 in Rabi season using cv. kufri pukhraj for the 
management of foliar fungal diseases of potato. Only one disease was observed, namely early blight of potato caused by $A$. solani [(Ell. \& Mart.) Jones and Grout]. The soil of the experimental field was sandy loam. The experiment was laid out in a randomized block design with three replications. All recommended agronomic practices were followed. The potato tubers were sown in the last week of November at a distance of $50 \mathrm{~cm}$ $X 20 \mathrm{~cm}$ spacing by using 20-25 q seed tubers $\mathrm{ha}^{-1}$ with the gross area of $6.0 \mathrm{~m} \times 3.0 \mathrm{~m}=$ $18.0 \mathrm{~m}^{2}$. Efficacies of nine fungicides (as below) were compared with untreated control.

Treatment details with their dose

\begin{tabular}{|c|l|c|}
\hline Treatment No. & \multicolumn{1}{|c|}{ Name of the Treatments } & Spray Conc. (gm/lit) \\
\hline $\mathbf{T}_{\mathbf{1}}$ & Fenamidone 10\% + Mancozeb 50\% WDG & 2.5 \\
\hline $\mathbf{T}_{\mathbf{2}}$ & Cymoxanil 8\% + Mancozeb 64\% WP & 2.5 \\
\hline $\mathbf{T}_{\mathbf{3}}$ & Dimethomorph 50\% WP & 1.0 \\
\hline $\mathbf{T}_{\mathbf{4}}$ & Fosetyl Al 80\% WP & 2.0 \\
\hline $\mathbf{T}_{\mathbf{5}}$ & Mancozeb 75 WP & 2.5 \\
\hline $\mathbf{T}_{\mathbf{6}}$ & Metalaxyl 8\% + Mancozeb 64\% WP & 2.0 \\
\hline $\mathbf{T}_{\mathbf{7}}$ & Captan 70\% + Hexaconazole 5\% WP & 1.0 \\
\hline $\mathbf{T}_{\mathbf{8}}$ & Metiram 55\% + Pyraclostrobin 5\% WG & 2.0 \\
\hline $\mathbf{T}_{\mathbf{9}}$ & Carbendazim 25\% + Mancozeb 50\% WS & 1.5 \\
\hline $\mathbf{T}_{\mathbf{1 0}}$ & Untreated Control & - \\
\hline
\end{tabular}

Three sprays of each fungicide with their prefixed concentration were applied at an interval of 15 days when the disease initiation was started. The per cent disease intensity was recorded as per three consecutive sprays of fungicides at 50, 60 and 70 days after sowing. On the basis of symptoms (Figure A and Figure B) and microscopic studies, the fungus was identified as Alternaria solani, causative agent of early blight of potato [(Ellis and Martin, 1882) Jones and Grout]. The observations on the intensity of early blight disease of potato were recorded from randomly selected 5 plants from each plot using 0-5 scale as mentioned below.

\begin{tabular}{|c|c|}
\hline Disease Score & Disease Intensity \\
\hline $\mathbf{0}$ & Leaves free from infection. \\
\hline 1 & Small irregular spots covering $<5 \%$ leaf area. \\
\hline 2 & $\begin{array}{l}\text { Small irregular brown spots with concentric rings covering } 5.1-10 \% \text { leaf } \\
\text { area. }\end{array}$ \\
\hline 3 & $\begin{array}{l}\text { Lesions enlarging, irregular brown with concentric rings covering } 10.1 \text { - } \\
25 \% \text { leaf area. }\end{array}$ \\
\hline 4 & $\begin{array}{l}\text { Lesions coalease to form irregular and appears as a typical blight } \\
\text { symptom covering } 25.1-50 \% \text { leaf area. }\end{array}$ \\
\hline 5 & $\begin{array}{l}\text { Lesions coalease to form irregular and appears as a typical blight } \\
\text { symptom covering }>50 \% \text { leaf area. }\end{array}$ \\
\hline
\end{tabular}


Per cent Disease Intensity (PDI) was calculated by using the following formula given by Chestar, 1959 and Weeler, 1969.

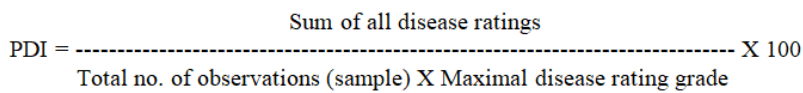

Based on these observations, per cent disease intensity (PDI) of early blight of potato was recorded. The per cent disease intensity data was arcsine transformed before analysis of variance (ANOVA). Statistical analysis was done with using the standard procedure described by Gomez and Gomez (1986).

\section{Results and Discussion}

\section{Effect of fungicides on the disease intensity of early blight of potato}

The experiment was conducted successfully at ARS, Ladol and PRS, Deesa farm with susceptible variety kufri pukhraj. We visually observed only one major disease infestation in the experiment. It was early blight disease caused by Alternaria solani [(Ellis \& Martin) Jones \& Grout]. There was no tuber infection found at the time of harvesting.

\section{Agricultural research station, Ladol}

The data on PDI of early blight of potato was recorded periodically at 50,60 and 70 days after sowing with consecutive three spray of fungicides at 15 days interval and was found low to moderate in range $(11.51-37.98)$ per cent. The data revealed that all fungicides tested reduced the disease intensity significantly as compared to control during 2015-16, 2016-17, and 2017-18 and pooled also (Table 1).

In the year 2015-16, the minimum per cent disease intensity was observed at 70 DAS in $\mathrm{T}_{1}$ i.e. spraying of fenamidone $10 \%+$ mancozeb 50\% WDG @ $0.15 \%(12.94 \%)$ and it was at par with treatment $\mathrm{T}_{8}$ i.e. spraying of metiram $55 \%+$ pyraclostrobin 5 $\%$ WG @0.1\% (14.04\%) as compared to control (20.64\%). In the year 2016-17, the minimum per cent disease intensity was observed at 70 DAS in the same treatment $T_{1}$ i.e. spraying of fenamidone $10 \%+$ mancozeb 50\%WDG@0.15\% (11.51\%) and it was at par with treatments $\mathrm{T}_{8}$ i.e. metiram $55 \%+$ pyraclostrobin $5 \%$ WG @ $0.1 \%$ (11.92\%) and $\mathrm{T}_{2}$ i.e. spraying of cymoxanil $8 \%+$ mancozed $64 \%$ WP @ $0.2 \%$ (12.69\%) as compared to control $(20.22 \%)$. In the next year, the minimum per cent disease intensity was recorded at 70 DAS repeatedly in the treatment $\mathrm{T}_{1}$ i.e. spraying of fenamidone $10 \%$ + mancozeb 50\% WDG @ $0.15 \%$ (23.66 \%) and it was at par with the treatment $\mathrm{T}_{8}$ i.e. metiram 55\% + pyraclostrobin 5\% WG @ $0.1 \%(25.02 \%)$ as compared to control (37.98\%). Here, treatment $\mathrm{T}_{1}$ i.e. fenamidone $10 \%$ + mancozeb 50\% WDG @0.15\% found significantly superior over rest of the treatments during 2015-16 to 2017-18 as well as in pooled also.

In pooled data, the minimum PDI at 70 DAS was found in treatment $\mathrm{T}_{1}$ i.e. spraying of fenamidone $10 \%$ + mancozeb 50\%WDG @ $0.15 \%(16.04 \%)$ whereas, two treatments followed $\mathrm{T}_{8}$ i.e. spraying of metiram $55 \%+$ pyraclostrobin $5 \% \mathrm{WG} @ 0.1 \%$ and $\mathrm{T}_{2}$ i.e. spraying of cymoxanil $8 \%+$ mancozed $64 \%$ WP@ $0.2 \%$ were at par with the treatment $\mathrm{T}_{1}$ with its PDI 16.99 and $17.92 \%$. which were also produced significantly lower per cent disease intensity as compared to control.

Thus, application of fenamidone $10 \%+$ mancozeb 50\% WDG @ $0.15 \%$ found best for management of early blight in potato. Later on, metiram $55 \%+$ pyraclostrobin $5 \%$ WG@ $0.1 \%$ and cymoxanil $8 \%+$ mancozed $64 \%$ WP @ $0.2 \%$ during the course of investigation. 


\section{Potato research station, Deesa}

The data on PDI of early blight of potato was recorded periodically at 50,60 and 70 days after sowing with consecutive three spray of fungicides at 15 days interval and was found low to moderate in range $(10.07-24.62$ per cent). It is revealed from the data that there was significant difference in per cent disease intensity during 2015-16, 2016-17, and 201718 and pooled also (Table 1 ).

In the year 2015-16, the minimum per cent disease intensity was observed at 70 DAS in $\mathrm{T}_{1}$ i.e. spraying of fenamidone $10 \%+$ mancozeb 50\% WDG @ $0.15 \%$ (11.89\%) and it was at par with treatment $\mathrm{T}_{2}$ i.e. spraying of cymoxanil $8 \%+$ mancozed $64 \%$ WP @ $0.2 \%(14.02 \%)$ as compared to control $(22.00 \%)$.

In the year 2016-17, the minimum per cent disease intensity was observed at 70 DAS in the same treatment $\mathrm{T}_{1}$ i.e. spraying of fenamidone $10 \%$ + mancozeb 50\%WDG @ $0.15 \%(13.03 \%)$ and it was at par with treatments $\mathrm{T}_{2}$ i.e. spraying of cymoxanil $8 \%$ + mancozed $64 \%$ WP @ $0.2 \%(15.23 \%)$ as compared to control $(24.62 \%)$. In the next year, the minimum per cent disease intensity was recorded at 70 DAS repeatedly in the treatment $\mathrm{T}_{1}$ i.e. spraying of fenamidone $10 \%$ + mancozeb 50\% WDG @ $0.15 \%(10.07 \%)$ and it was at par with the treatment $\mathrm{T}_{2}$ i.e. spraying of cymoxanil $8 \%+$ mancozed $64 \%$ WP @ $0.2 \%(12.54 \%)$ as compared to control $(22.87 \%)$.

Here, treatment $\mathrm{T}_{1}$ i.e. fenamidone $10 \%+$ mancozeb 50 \% WDG @ $0.15 \%$ found significantly superior over rest of the treatments during 2015-16 to 2017-18 as well as in pooled also. In pooled data, the minimum PDI at 70 DAS was found in treatment $\mathrm{T}_{1}$ i.e. spraying of fenamidone $10 \%$ + mancozeb 50\% WDG @ $0.15 \%$ (11.95\%) followed by $\mathrm{T}_{2}$ i.e. spraying of cymoxanil $8 \%$ + mancozed $64 \%$ WP @ $0.2 \%$ with its PDI 14.04. Which was also produced significantly lower per cent disease intensity as compared to control. Thus, application of fenamidone $10 \%$ + mancozeb 50 \% WDG @ $0.15 \%$ found better for management of early blight in potato at Potato Research Station also. Later on, cymoxanil $8 \%+$ mancozed $64 \%$ WP @ $0.2 \%$ during the course of investigation.

\section{Effect of fungicides on the yield of potato tubers}

\section{Agricultural research station, Ladol}

Effect of different treatments on potato tuber yield was found significant during all the years and pooled also (Table 2). During the year 2015-16, spraying of fenamidone $10 \%+$ mancozeb 50\%WDG @ 0.15\% recorded significantly higher yield and found superior over rest of the treatments. In 2015-16, treatment $\mathrm{T}_{1}$ i.e. spraying of fenamidone $10 \%$ + mancozeb 50\% WDG @ 0.15\% recorded significantly the maximum yield (60574 $\mathrm{kg} / \mathrm{ha}$ ) of potato and it was at par with treatments $\mathrm{T}_{8}$ i.e. spraying of metiram $55 \%+$ pyraclostrobin $5 \%$ WG @ $0.1 \%$ with the yield $56778 \mathrm{~kg} / \mathrm{ha}$, In the year 2016-17, treatment $\mathrm{T}_{1}$ i.e. spraying of fenamidone $10 \%$ + mancozeb 50\%WDG @0.15\% recorded significantly higher yield as compare with control and it was found at par with treatments $\mathrm{T}_{8}, \mathrm{~T}_{2}, \mathrm{~T}_{9}, \mathrm{~T}_{7}$ and $\mathrm{T}_{5}$. In the third year (2017-18), treatment $\mathrm{T}_{1}$ repeatedly recorded higher yield (48093 $\mathrm{kg} / \mathrm{ha})$ and it was at par with the treatments $\mathrm{T}_{8}$ and $\mathrm{T}_{2}$ with its yield 46333 and $45778 \mathrm{~kg} / \mathrm{ha}$, respectively.

In pooled data, spraying of fenamidone $10 \%$ + mancozeb 50\% WDG @ 0.15\% showed the maximum yield and statistically near with the treatments $\mathrm{T}_{8}$. Both were found significantly superior over rest of the treatments. 


\section{Potato research station, Deesa}

Effect of different treatments on potato tuber yield was found significant during all the years and pooled also (Table 2). During the year 2015-16, spraying of fenamidone $10 \%+$ mancozeb $50 \%$ WDG @ $0.15 \%$ recorded significantly higher yield and found superior over rest of the treatments. In 2015-16, treatment $\mathrm{T}_{1}$ i.e. spraying of fenamidone $10 \%$ + mancozeb 50\% WDG @ 0.15\% recorded significantly the maximum yield (46159 $\mathrm{kg} / \mathrm{ha}$ ) of potato and it was found at par with treatments $\mathrm{T}_{2}, \mathrm{~T}_{9}$ and $\mathrm{T}_{5}$. In 2016-17, treatment $\mathrm{T}_{1}$ i.e. spraying of fenamidone $10 \%$ + mancozeb 50\%WDG @ 0.15\% recorded significantly higher yield as compare with control and it was found at par with treatments $\mathrm{T}_{2}, \mathrm{~T}_{9}, \mathrm{~T}_{7}$ and $\mathrm{T}_{5}$. In the third year (2017-18), treatment $T_{1}$ repeatedly recorded higher yield $(52486 \mathrm{~kg} / \mathrm{ha})$ and it was at par with the treatments $\mathrm{T}_{2}, \mathrm{~T}_{9}, \mathrm{~T}_{7}$ and $\mathrm{T}_{5}$. In pooled data, spraying of fenamidone $10 \%+$ mancozeb 50\%WDG @ 0.15\% showed the maximum yield and found significantly superior over rest of the treatments.

Higher yield under this treatment might be due to better control of blight by these combination fungicide formulation (fenamidone $10 \%+$ mancozeb $50 \%$ ). Thus, spraying of fenamidone $10 \%+$ mancozeb 50 \%WDG@0.15\% found effective fungicide not only in terms of control of early blight but increase the yield also.

\section{Economics}

In this experiment, the maximum net realization of Rs. 226442 with BCR 2.73 was obtained in the treatment fenamidone $10 \%+$ $\begin{array}{lllllll}\text { mancozeb } & 50 & \% & \mathrm{WDG} & @ & 0.15 & \%\end{array}$ concentration, $2.5 \mathrm{~g} /$ litre $\left(\mathrm{T}_{1}\right)$ followed by metiram $55 \%$ + pyraclostrobin 5\% WG @ $0.1 \%$ concentration, $2.0 \mathrm{ml} /$ litre $\left(\mathrm{T}_{8}\right)$ and cymoxanil $8 \%+$ mancozed $64 \%$ WP @ 0.2
$\%$ concentration, $2.5 \mathrm{ml} /$ litre $\left(\mathrm{T}_{2}\right)$ with net realization Rs. 214486, BCR 2.64 and Rs. 199210, BCR 2.47, respectively (Table 3).

Result of the present study showed that among the nine different fungicide treatments, two combination fungicides viz., $\mathrm{T}_{1}$ (fenamidone 10\% + mancozeb 50\% WDG) @ $0.2 \%$ (2.5 gm/litre) and $\mathrm{T}_{8}$ (metiram 55\% + pyraclostrobin $5 \% \quad \mathrm{WG})$ @ $\quad 0.2 \% \quad(2.0$ $\mathrm{gm} /$ litre) were found significantly superior for the management of early blight of potato disease as compared to others. These fungicides acted as the best fungicides when applied as prophylactic as well as curative measures. Other fungicides such as $\mathrm{T}_{2}$ (cymoxanil 8\% + mancozeb 64\% WP) @ $0.2 \%(2.5 \mathrm{gm} / \mathrm{l}), \mathrm{T}_{9}$ (carbendazim $25 \%+$ mancozeb 50\% WS) @ 0.2\% (2.0 gm/l) and $\mathrm{T}_{5}$ (mancozeb $\left.75 \mathrm{WP}\right) @ 0.2 \%$ (2.7 gm/litre) were also found effective against A. solani after $\mathrm{T}_{1} \& \mathrm{~T}_{8}$ treatments. Similar results were obtained by Asit et al., 2017, they tested sequential spraying of fenamidone $10 \%+$ mancozeb $50 \%$ WDG $(0.25 \%)$ two to three times from 45 day after transplanting at 10 days intervals for better management of early blight of tomato, enhancement of fruit yield and assurance of high economic return. They found minimum disease incidence $(10.61 \%)$ in case of involving fungicides (Fenamidone $10 \%$ + Mancozeb 50\% WDG) having both systemic and contact action gave better reduction of early blight disease over other treatment combinations in tomato. Preventive fungicides inhibit the spore germination and penetration but pathogen can derive resistance against fungicide application so repeated application of fungicides at proper dose and interval of time is mandatory (Hossain and Hossain, 2009). Best disease control with highest yields and fruit quality was reported in combination product of pyraclostrobin + metiram effective against both early blight and late blight has reported by Capriotti et al., (2005). 
Table.1 Efficacy of fungicides tested as foliar spray on intensity of early blight disease of potato at ARS, Ladol and PRS, Deesa (2015-16 to 2017-18)

\begin{tabular}{|c|c|c|c|c|c|c|c|c|c|}
\hline \multirow[t]{4}{*}{ Sr. } & \multirow[t]{4}{*}{ Treatments } & \multicolumn{8}{|c|}{ Per cent Disease Intensity (PDI) } \\
\hline & & \multirow{2}{*}{\multicolumn{2}{|c|}{$\begin{array}{c}2015-16 \\
\text { At } 70 \text { DAS }\end{array}$}} & \multirow{2}{*}{\multicolumn{2}{|c|}{$\begin{array}{c}2016-17 \\
\text { At } 70 \text { DAS }\end{array}$}} & \multirow{2}{*}{\multicolumn{2}{|c|}{$\begin{array}{c}2017-18 \\
\text { At } 70 \text { DAS }\end{array}$}} & \multirow{2}{*}{\multicolumn{2}{|c|}{ Pooled }} \\
\hline & & & & & & & & & \\
\hline & & ARS, Ladol & PRS, Deesa & ARS, Ladol & PRS, Deesa & ARS, Ladol & PRS, Deesa & ARS, Ladol & PRS, Deesa \\
\hline 1 & $\mathrm{~T}_{1} @ 0.15 \%$ & $\begin{array}{l}12.94^{\mathrm{g}} \\
(5.03)^{*}\end{array}$ & $\begin{array}{l}11.89^{\mathrm{e}} \\
(4.44)\end{array}$ & $\begin{array}{l}11.51^{\mathrm{g}} \\
(4.00)\end{array}$ & $\begin{array}{l}13.03^{\mathrm{e}} \\
(5.18)\end{array}$ & $\begin{array}{l}23.66^{g} \\
(16.14)\end{array}$ & $\begin{array}{c}10.07^{\mathrm{e}} \\
(3.33)\end{array}$ & $\begin{array}{l}16.04^{\mathrm{g}} \\
(8.39)\end{array}$ & $\begin{array}{l}11.95^{\mathrm{g}} \\
(4.32)\end{array}$ \\
\hline 2 & $\mathrm{~T}_{2} @ 0.2 \%$ & $\begin{array}{l}14.94^{\text {ef }} \\
(6.66)\end{array}$ & $\begin{array}{l}14.02^{\mathrm{de}} \\
(5.93)\end{array}$ & $\begin{array}{l}12.69^{\mathrm{fg}} \\
(4.88)\end{array}$ & $\begin{array}{l}15.23^{\mathrm{de}} \\
(7.04)\end{array}$ & $\begin{array}{l}26.12^{\text {ef }} \\
(19.40)\end{array}$ & $\begin{array}{l}12.54^{\mathrm{de}} \\
(4.81)\end{array}$ & $\begin{array}{l}17.92^{\text {efg }} \\
(10.32)\end{array}$ & $\begin{array}{l}14.04^{f} \\
(5.93)\end{array}$ \\
\hline 3 & $\mathrm{~T}_{3} @ 0.05 \%$ & $\begin{array}{l}19.45^{a b} \\
(11.11)\end{array}$ & $\begin{array}{l}18.06^{b c} \\
(9.63)\end{array}$ & $\begin{array}{l}17.91^{b c} \\
(9.48)\end{array}$ & $\begin{array}{l}22.011^{a b} \\
(14.07)\end{array}$ & $\begin{array}{l}33.14^{b} \\
(29.92)\end{array}$ & $\begin{array}{l}20.40^{a b} \\
(12.22)\end{array}$ & $\begin{array}{l}23.50^{b c} \\
(16.83)\end{array}$ & $\begin{array}{l}20.18^{b} \\
(11.97)\end{array}$ \\
\hline 4 & $\mathrm{~T}_{4} @ 0.15 \%$ & $\begin{array}{l}20.38^{a} \\
(12.15)\end{array}$ & $\begin{array}{l}18.41^{b} \\
(10.00)\end{array}$ & $\begin{array}{l}18.90^{a b} \\
(10.51)^{a}\end{array}$ & $\begin{array}{l}23.14^{\mathrm{ab}} \\
(15.55)\end{array}$ & $\begin{array}{l}34.88^{b} \\
(32.74)\end{array}$ & $\begin{array}{l}20.02^{a b} \\
(11.85)\end{array}$ & $\begin{array}{l}24.72^{a b} \\
(18.47)\end{array}$ & $\begin{array}{c}20.59^{b} \\
(12.47)\end{array}$ \\
\hline 5 & $\mathrm{~T}_{5} @ 0.2 \%$ & $\begin{array}{c}16.09^{\mathrm{de}} \\
(7.70)\end{array}$ & $\begin{array}{l}15.37^{\mathrm{cd}} \\
(7.04)\end{array}$ & $\begin{array}{l}14.93^{\mathrm{de}} \\
(6.66)\end{array}$ & $\begin{array}{l}18.41^{\mathrm{cd}} \\
(10.00)\end{array}$ & $\begin{array}{l}28.71^{d} \\
(23.11)\end{array}$ & $\begin{array}{l}16.53^{\text {bcd }} \\
(8.15)\end{array}$ & $\begin{array}{l}19.91^{\mathrm{de}} \\
(12.49)\end{array}$ & $\begin{array}{l}16.79^{\mathrm{de}} \\
(8.39)\end{array}$ \\
\hline 6 & $\mathrm{~T}_{6} @ 0.15 \%$ & $\begin{array}{c}18.20^{b c} \\
(9.77)\end{array}$ & $\begin{array}{l}16.57^{\mathrm{bcd}} \\
(8.15)\end{array}$ & $\begin{array}{l}16.26^{\mathrm{cd}} \\
(7.85)\end{array}$ & $\begin{array}{l}19.79^{b c} \\
(11.48)\end{array}$ & $\begin{array}{l}30.68^{c} \\
(26.07)\end{array}$ & $\begin{array}{c}18.03^{\mathrm{bc}} \\
(9.63)\end{array}$ & $\begin{array}{l}21.71^{\mathrm{cd}} \\
(14.56)\end{array}$ & $\begin{array}{l}18.15^{\mathrm{cd}} \\
(9.75)\end{array}$ \\
\hline 7 & $\mathrm{~T}_{7} @ 0.1 \%$ & $\begin{array}{c}16.71^{\mathrm{cd}} \\
(8.29)\end{array}$ & $\begin{array}{l}16.95^{b c} \\
(8.52)\end{array}$ & $\begin{array}{l}15.43^{\mathrm{de}} \\
(7.11)^{-}\end{array}$ & $\begin{array}{l}18.06^{\mathrm{cd}} \\
(9.63)\end{array}$ & $\begin{array}{l}27.38^{\mathrm{de}} \\
(21.18)\end{array}$ & $\begin{array}{l}16.10^{\mathrm{bcd}} \\
(7.78)\end{array}$ & $\begin{array}{l}19.84^{\mathrm{de}} \\
(12.20)\end{array}$ & $\begin{array}{l}17.07^{\mathrm{de}} \\
(8.64)\end{array}$ \\
\hline 8 & $\mathrm{~T}_{8} @ 0.1 \%$ & $\begin{array}{l}14.04^{\mathrm{fg}} \\
(5.92)\end{array}$ & $\begin{array}{c}18.41^{\mathrm{b}} \\
(10.00)\end{array}$ & $\begin{array}{l}11.92^{g} \\
(4.29)\end{array}$ & $\begin{array}{l}20.75^{b c} \\
(12.59)\end{array}$ & $\begin{array}{l}25.02^{\mathrm{fg}} \\
(17.92)\end{array}$ & $\begin{array}{l}18.74^{a b c} \\
(10.37)\end{array}$ & $\begin{array}{l}16.99^{\mathrm{fg}} \\
(9.38)\end{array}$ & $\begin{array}{l}19.33^{b c} \\
(10.99)\end{array}$ \\
\hline 9 & $\mathrm{~T}_{9} @ 0.1 \%$ & $\begin{array}{c}15.76^{\mathrm{de}} \\
(7.41)\end{array}$ & $\begin{array}{l}15.37^{\mathrm{cd}} \\
(7.04)\end{array}$ & $\begin{array}{l}14.04^{\text {ef }} \\
(5.92)\end{array}$ & $\begin{array}{l}17.31^{\mathrm{cd}} \\
(8.89)\end{array}$ & $\begin{array}{l}26.86^{\mathrm{e}} \\
(20.44)\end{array}$ & $\begin{array}{l}15.31^{\mathrm{cd}} \\
(7.04)\end{array}$ & $\begin{array}{l}18.89^{\text {ef }} \\
(11.26)\end{array}$ & $\begin{array}{l}16.03^{\mathrm{e}} \\
(7.65)\end{array}$ \\
\hline 10 & $\mathrm{~T}_{10}($ Control $)$ & $\begin{array}{l}20.64^{a} \\
(12.44)\end{array}$ & $\begin{array}{c}22.00^{\mathrm{a}} \\
(14.07)^{-}\end{array}$ & $\begin{array}{c}20.22^{a} \\
(12.00)\end{array}$ & $\begin{array}{c}24.62^{\mathrm{a}} \\
(17.41)\end{array}$ & $\begin{array}{l}37.98^{a} \\
(37.92)\end{array}$ & $\begin{array}{c}22.87^{\mathrm{a}} \\
(15.19)\end{array}$ & $\begin{array}{c}26.28^{a} \\
(20.79)\end{array}$ & $\begin{array}{r}23.20^{\mathrm{a}} \\
(15.56)\end{array}$ \\
\hline & S.Em $( \pm)$ & 0.47 & 0.82 & 0.57 & 1.03 & 0.54 & 1.34 & 0.67 & 0.45 \\
\hline & C.D at $5 \%$ & 1.42 & 2.46 & 1.73 & 3.09 & 1.6 & 4.03 & 2.01 & 1.36 \\
\hline & C.V. (\%) & 4.86 & 8.50 & 6.50 & 9.299 & 3.8 & 13.65 & 4.48 & 4.42 \\
\hline & Y X T & & & & & & & $\mathrm{S}$ & NS \\
\hline
\end{tabular}

* Figures in the parenthesis are original values; DAS-Day after sowing; Superscript denotes DNMRT ranking Note: Treatment means with the common letters are not significant by DNMRT at $5 \%$ level of significance. ARS: Agricultural Research Station; PRS: Potato Research Station 
Table.2 Effect of different treatments on potato tuber yield at ARS, Ladol and PRS, Deesa (2015-16 to 2017-18)

\begin{tabular}{|c|c|c|c|c|c|c|c|c|c|}
\hline \multirow{3}{*}{$\begin{array}{l}\text { Sr. } \\
\text { No. }\end{array}$} & \multirow[t]{3}{*}{ Name of Treatments } & \multicolumn{8}{|c|}{ Potato Yield, kg/ha } \\
\hline & & \multicolumn{2}{|c|}{$2015-16$} & \multicolumn{2}{|c|}{ 2016-17 } & \multicolumn{2}{|c|}{$2017-18$} & \multicolumn{2}{|c|}{ Pooled } \\
\hline & & ARS, Ladol & PRS, Deesa & ARS, Ladol & PRS, Deesa & ARS, Ladol & PRS, Deesa & ARS, Ladol & PRS, Deesa \\
\hline $\mathbf{T}_{1}$ & $\begin{array}{l}\text { Fenamidone } 10 \%+\text { Mancozeb } 50 \% \\
\text { WDG }\end{array}$ & $60574^{a}$ & $46159^{a}$ & $45981^{a}$ & $56337^{a}$ & $48093^{a}$ & $52486^{a}$ & $51549^{a}$ & $51661^{a}$ \\
\hline $\mathbf{T}_{2}$ & Cymoxanil $8 \%+$ Mancozed $64 \%$ WP & $50352^{\mathrm{bc}}$ & $43130^{a b}$ & $43796^{a b}$ & $53538^{a b}$ & $45778^{a b}$ & $50285^{a b}$ & $46642^{b c}$ & $48984^{\mathrm{ab}}$ \\
\hline $\mathbf{T}_{\mathbf{3}}$ & Dimethomorph $50 \% \mathrm{WP}$ & $44444^{c}$ & $36730^{\mathrm{bcd}}$ & $38500^{b c}$ & $46587^{b c}$ & $32130^{\mathrm{cd}}$ & $41615^{b c}$ & $38358^{\text {ef }}$ & $41644^{\text {ef }}$ \\
\hline $\mathbf{T}_{4}$ & Fosetyl Al $80 \%$ WP & $44296^{c}$ & $36867^{\mathrm{bcd}}$ & $38204^{b c}$ & $47979^{b c}$ & $32111^{\mathrm{cd}}$ & $42642^{b c}$ & $38204^{\text {ef }}$ & $42496^{\text {de }}$ \\
\hline $\mathbf{T}_{5}$ & Mancozeb 75 WP & $45648^{c}$ & $40185^{\text {abcd }}$ & $40574^{a b c}$ & $50490^{a b}$ & $34741^{\mathrm{cd}}$ & $48674^{\mathrm{ab}}$ & $40321^{\text {def }}$ & $46449^{\mathrm{bcd}}$ \\
\hline $\mathbf{T}_{6}$ & Metalaxyl $8 \%+$ Mencozeb $64 \%$ WP & $44537^{c}$ & $37611^{b c d}$ & $39759^{a}$ & $47385^{b c}$ & $33926^{\mathrm{cd}}$ & $44146^{a b c}$ & $39407^{\text {ef }}$ & $43048^{\text {cde }}$ \\
\hline $\mathbf{T}_{7}$ & Captan 70\% + Hexaconazole 5\% WP & $45500^{\mathrm{c}}$ & $38952^{\text {abcd }}$ & $41815^{a b c}$ & $50928^{a b}$ & $38111^{\text {bcd }}$ & $48965^{a b}$ & $41809^{\mathrm{de}}$ & $46282^{\mathrm{bcd}}$ \\
\hline $\mathbf{T}_{8}$ & Metiram 55\% + Pyraclostrobin 5\% WG & $56778^{a b}$ & $34111^{\mathrm{cd}}$ & $44815^{\mathrm{a}}$ & $47427^{\mathrm{bc}}$ & $46333^{a b}$ & $43976^{a b c}$ & $49309^{a b}$ & $41838^{\text {def }}$ \\
\hline $\mathbf{T}_{9}$ & $\begin{array}{l}\text { Carbendazim 25\%+ Mancozeb } 50 \% \\
\text { WS }\end{array}$ & $49648^{b c}$ & $41163^{a b c}$ & $43056^{\mathrm{abc}}$ & $52139^{a b}$ & $40407^{\mathrm{abc}}$ & $49243^{\mathrm{ab}}$ & $44370^{\mathrm{cd}}$ & $47515^{a b c}$ \\
\hline \multirow[t]{5}{*}{$\mathbf{T}_{10}$} & Control (Water spray) & $41926^{c}$ & $33250^{d}$ & $37630^{c}$ & $41486^{c}$ & $31870^{d}$ & $39392^{c}$ & $37142 \mathrm{f}$ & $38043^{t}$ \\
\hline & S.Em $( \pm)$ & 2793 & 2267 & 1829 & 2405 & 2546 & 2739 & 1321 & 1431 \\
\hline & C.D at $5 \%$ & 8298 & 6735 & 5433 & 7146 & 7564 & 8138 & 3924 & 4057 \\
\hline & C.V. $(\%)$ & 10.0 & 10.12 & 7.65 & 8.43 & 11.50 & 10.28 & 9.83 & 9.58 \\
\hline & Y X T & & & & & & & NS & NS \\
\hline
\end{tabular}

Superscript denotes DNMRT ranking

Note: Treatment means with the common letters are not significant by DNMRT at $5 \%$ level of significance.

ARS: Agricultural Research Station; PRS: Potato Research Station 
Table.3 Economics of different treatments

\begin{tabular}{|c|c|c|c|c|c|c|}
\hline $\begin{array}{l}\text { Sr. } \\
\text { No }\end{array}$ & Treatment Details & $\begin{array}{c}\text { Yield } \\
\text { Kg/ha }\end{array}$ & $\begin{array}{l}\text { Gross Realization } \\
\text { (Rs.) }\end{array}$ & $\begin{array}{l}\text { Cost of } \\
\text { Inputs }\end{array}$ & $\begin{array}{l}\text { Net Realization } \\
\text { (Rs.) }\end{array}$ & BCR \\
\hline 1 & $\begin{array}{l}\text { Fenamidone } 10 \%+\text { Mancozeb } 50 \% \\
\text { WDG }\end{array}$ & 51549 & 309294 & 82852 & 226442 & 2.73 \\
\hline 2 & $\begin{array}{l}\text { Cymoxanil } 8 \%+\text { Mancozed } 64 \% \\
\text { WP }\end{array}$ & 46642 & 279852 & 80642 & 199210 & 2.47 \\
\hline 3 & Dimethomorph $50 \%$ WP & 38358 & 230148 & 83672 & 146476 & 1.75 \\
\hline 4 & Fosetyl Al $80 \%$ WP & 38204 & 229224 & 80952 & 148272 & 1.83 \\
\hline 5 & Mancozeb 75 WP & 40321 & 241926 & 79692 & 162234 & 2.04 \\
\hline 6 & $\begin{array}{l}\text { Metalaxyl } 8 \%+\text { Mencozeb } 64 \% \\
\text { WP }\end{array}$ & 39407 & 236442 & 80352 & 156090 & 1.94 \\
\hline 7 & $\begin{array}{l}\text { Captan } 70 \%+\text { Hexaconazole } 5 \% \\
\text { WP }\end{array}$ & 41809 & 250854 & 80332 & 170522 & 2.12 \\
\hline 8 & $\begin{array}{l}\text { Metiram 55\% + Pyraclostrobin 5\% } \\
\text { WG }\end{array}$ & 49309 & 295854 & 81368 & 214486 & 2.64 \\
\hline 9 & $\begin{array}{l}\text { Carbendazim 25\%+ Mancozeb 50\% } \\
\text { WS }\end{array}$ & 44370 & 266220 & 80192 & 186028 & 2.32 \\
\hline 10 & Control (Water spray) & 37142 & 222852 & 78772 & 144080 & 1.83 \\
\hline
\end{tabular}
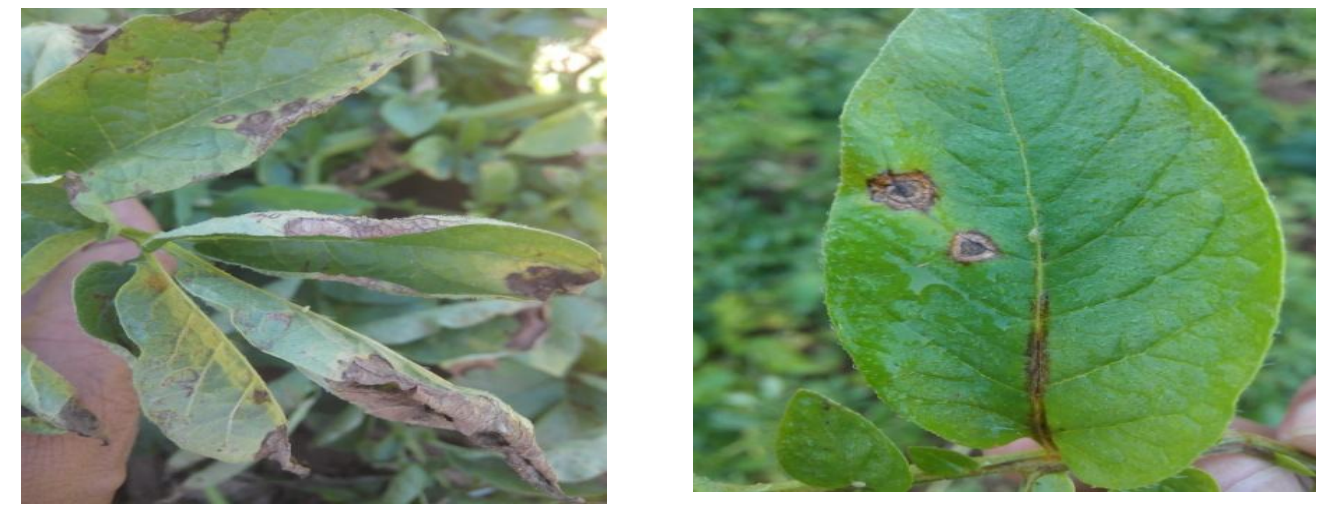

Figure.1 Concentric rings forms on infected leaves
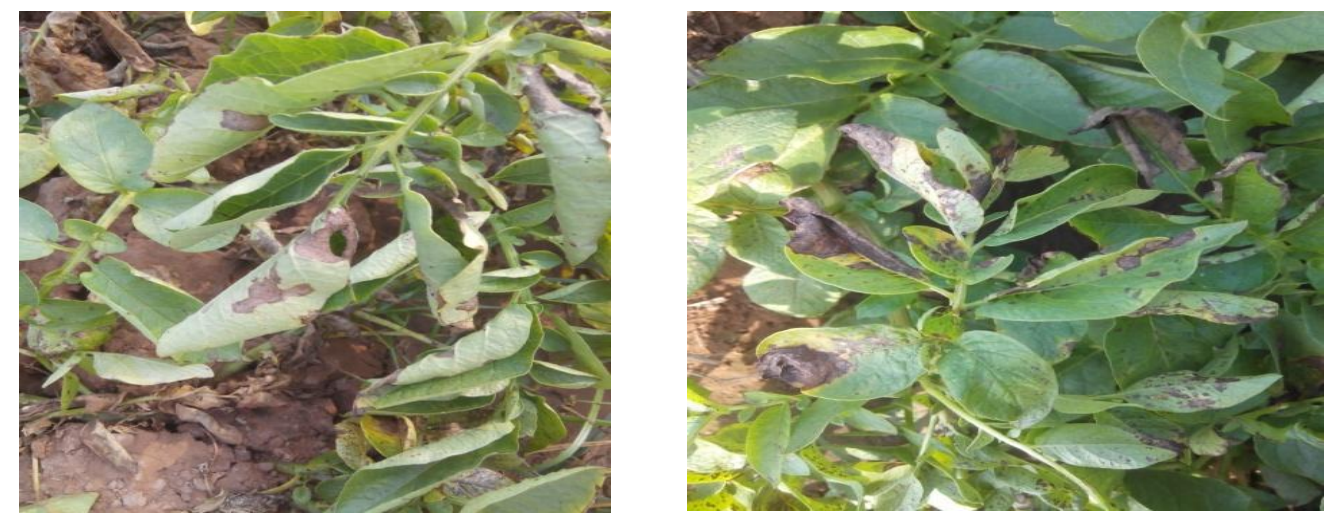

Figure.2 Alternaria or early blight of Potato Symptoms on Leaves 
Ganeshan and Chethna, (2009) also found pyraclostrobin $25 \%$ EC significantly reduced disease and resulted in increased yield as compared to captan, mancozeb and control. Arunakumara et al., 2010; Horsfield et al., 2010 and Sahu et al., 2013 also tested the efficacies of some newer fungicides in field conditions for the management of early blight of tomato and they found pyraclostrobin, azoxystrobin and carbendazim + mancozeb were highly effective for the management of early blight.

All the treatments showed significantly better foliage controlled as well as tuber yield over non- treated control. In 2018, kumar et al., evaluated 9 different systemic and contact fungicides in in vivo and in vitro Conditions. They found that fenamidone $10 \%+$ mancozeb $50 \%(0.2 \%)$ was most effective followed by propiconazole $25 \% \mathrm{EC}$, dimethomorph $9 \%+$ mancozeb $60 \%$, cymoxanil $8 \%+$ mancozeb $64 \%(0.2 \%)$ and mancozeb $(0.25 \%)$ and also economical in reducing severity of the early blight and increasing yield over control.

The results of this study were consistent with previous studies and indicated that the application of protective fungicides (combination of systemic and contact) could reduce foliar early blight to acceptable levels.

Thus, in the present study, it can be said that combination of systemic and contact fungicides may be effectively had suppression of pre as well as post-infection activity and inhibited sporulation and/or restricted lesion expansion of early blight pathogen. Also found not only to manage early blight but increase in the yield of potato as well.

\section{References}

Anonymous. 2009. Indian Horticulture Database 2009. http://nhb.gov.in/database.
Anonymous. 2017. Source: FAOSTAT. http://www.fao.org/

Anonymous. 2018. Monthly report potato (January 2018). Horticultural Statistics Division, Dept. of Agriculture, Cooperation \& Farmers Welfare, Ministry of Agriculture \& Farmers Welfare, Govt. of India. p. 9.

Arunkumara, K. T., Kulkarni, M. S., Thammaiah, N. and Hedge, Y. 2010. Fungicidal management of early blight of tomato. Indian Phytopathol. 63 (1): 96-97.

Asit, K. M., Praveen, K. M., Subrata, D. and Arup, C. 2017. Effective management of major tomato diseases in the gangetic plains of eastern India through integrated approach. Agri. Res. \& Tech. 10 (5): 555796.

Capriotti, M., Marchi, A., Coatti, M. and Manaresi, M. 2005. Cabriotop. The broad spectrum fungicide for the control of the main grapevine and tomato diseases. Informatore Fitopatologico. 55: 38- 45.

Chester, K. S. 1959. How sick is the plant? In "Plant Pathology an Advance Traits" (Eds J. G. Horsfall and A. E. Diamond) Vol.1, Academic Press, New York. pp. 199-242.

Ellis, J. B. and Martin, G. B. 1882. Macrosporium solani E\&M. Amer. Nat. 16: 1003.

Ganeshan, G. and Chethana, B. S. 2009. Bioefficacy of pyraclostrobin $25 \%$ EC against early blight of tomato. World Appl. Sci. J. 7 (2): 227-229.

Gomez, K. A. and Gomez, A. A. 1986. Statistical procedures for agriculture research. 2nd edition, John Wiley and Sons. pp. 680.

Horsfield, A., Wicks, T., Davies, C. K., Wilson, D. and Paton, S. 2010. Effect of fungicide use strategies on the control of early blight (Alternaria solani) and potato yield. Australas. Plant Pathol. 
39: 368-375.

Hossain, M. S. and Hossain, M. M. 2009. Efficacy of foliar fungicides in controlling early blight of tomato. Bangladesh J. Pl. Pathol. 25 (1/2): pp. 55.

Kumar, A., Pathak, S. P., Abhimanyu and Rai, J. P. 2018. Efficacy of newly fungicides on early blight of potato under in vivo and in vitro Conditions. Int.J.Curr.Microbiol.App.Sci. Special Issue-7: 16-22

Patel, H. V. 2007. Studies on early blight of tomato caused by Alternaria solani
(Ellis and Mart.) under north Gujarat conditions. M.Sc. (Agri.) Thesis, Submitted to Sardarkrushinagar Dantiwada Agricultural University, Sardarkrushinagar. pp. 68.

Sahu, D. K., Khare, C. P., Singh, H. K. and Thakur, M. P. 2013. Evalution of newer fungicide for management of early blight of tomato in Chattisgarh. The Bioscan. 8(4): 1255-1259.

Weeler, B. E. J. 1969. An Introduction to Plant Disease. John Willey and Sons Limited, London. pp 301.

\section{How to cite this article:}

Sharma. R. K., J. K. Patel, D. R. Patel and Patel. R. N. 2020. Management of Early Blight of Potato (Solanum tuberosum L.) caused by Alternaria solani [(Ellis \& Martin) Jones \& Grout] through Fungicides and its Impact on Yield. Int.J.Curr.Microbiol.App.Sci. 9(03): 1683-1693. doi: https://doi.org/10.20546/ijcmas.2020.903.196 